\title{
Community-Based Health Insurance Scheme as a way forward in Health financing in Nigerian Rural Areas of Sokoto State.
}

\author{
Garba Ibrahim Tanko
}

\begin{abstract}
Health financing in most of Sub Saharan Africa is based on out-of-pocket payment from the people. Because of out-of-pocket payment has caused so many families in SSA poor. This is to encourage people in SSA to implement Community-Based Health Insurance Scheme as the program is about risk pooling.

This is significant because it provides a chance for the people to be out of poverty as a result of high money paid whenever they are assessing health care through out-of-pocket payment at the point of service delivery. This view of community-based health insurance is a new area of health financing in the developing countries supported by the World Health Organization (WHO), World Bank (WB), International Labor Organization among others. In the SSA countries like Ghana, Mali, Burkina Faso has been very successful in this direction. In Nigeria, this concept of community-based health insurance plan is a new development so effort should be made to create awareness about this laudable project. But with CBHIS health care services would be provided based on the needs of the community. And as the focal point of CBHIS is the informal sector and the vast majority of the Nigerian people are located in the rural areas. the majority of the diseases that are killing our people are mostly communicable and preventable diseases. The management of the CBHIS is going to be by the rural people who will appoint among themselves those that are capable of the job. While, the Health Maintenance Organization are charged by the law to supervise the activities of these CBHIS.
\end{abstract}

Keywords: Health Financing, Out-of-Pocket, Sokoto, Community-Based Health Insurance

\section{Introduction}

Health insurance seen as a way of distributing the financial risk associated with the variation of individual's health care expenditures by pooling costs over time through pre-payment and other people with risk pooling (OECD, 2004). The health insurance policy seeks to remove financial barriers to receiving an acceptable level of health care and requires the wealthy to share in the cost of care of the sick; the element of cross-subsidy is essential (Enthoven 1988). Moreover, 'when a society considers providing for health care by offering health insurance, to some significant degree, at the public's expense, such insurance programs provided through taxes or regulations called social insurance programs' (WHO 2010; Carrin and James 2004; Folland et al, 2004). In view of this, there need arises for the government to set in motion policies and practices that will encourage the use of community health insurance scheme. According to Rosenthal (2001), rural dwellers may be less inclined to seek health services owing to the rising costs of medical services, if the integrated health insurance scheme as established by the state.

The need to develop a comprehensive health insurance scheme dated back to the middle ages. The responsibility of providing medical care for the sick and injured was vested in the family, neighbors, church, king (for his people), master (for his servants) and employer (for his employees). The focus is to make medical care available to everybody through the private resources for care but with national public funding, with a total funding to be determined by national policy.

Social health insurance has been developing for more than a century following its establishment in Germany by Bismarck in 1883 (Saltman and Dubois 2004). Worldwide, so far 27 nations have recognized the standard of universal coverage by means of Social Health Insurance (Carrin and James 2005). This process took 127 years to achieve in Germany, 118 in Belgium, 79 in Austria, 72 in Luxembourg, 48 in Japan, and 26 in the Republic of Korea.

SHI has been implemented in so many developing countries such as Thailand, Philippines, Kenya, Ghana and lately in Nigeria. These countries have been implementing social health insurance in their different countries and some of these countries were able to achieve universal health coverage while some are still struggling to introduce and implement the social health insurance scheme.

In a nutshell, community based health insurance scheme is becoming an emerging concept for providing and protecting rural dwellers against illness and injuries. Community based health insurance is a form of micro health insurance which is mainly used in rural areas "in developing countries". According to Churchill (2006), community based health insurance is a scheme of insurance that protects low-income people against specific perils in swap for regular premium payments balanced to the likelihood and cost of the risk concerned. 
This new approach is a general practice, which improves accessibility to quality health services for low-income rural households who are excluded from the National Health Insurance Scheme.

Good health is necessary for the health of the rural dwellers. Good health is also required for economic and social development (World Health Organization, 2000). Workers have to be healthy to work, and children have to be healthy to attend school and partake in other activities. Inadequate health facility is often associated with disease and injuries among the rural dwellers. At the same time, poor health has another critical impact: it causes poverty, in that large health expenditure can bankrupt families. According to WHO (2000) the main causes of poor health are insufficient prevention and lack of practical access to primary health care, along with poor nutrition and impure water, while health related poverty consequences beginning a lack of risk pooling and insurance Underfunding of healthcare by government and private organization is central to both of these negative effects. Furthermore, many countries compound these problems by making inefficient use of the resources they have for health care and risk pooling. Solutions could be sought through the use of the workable health insurance plan that can improve the well being of the rural dwellers.

Scholars are of the opinion that the success of community based health insurance scheme is premised on the existence of social capital in the community. It is postulated by Woolcock and Narayan (2000) that social capital refers to the norms and networks that allow individuals to act collectively. Fukuyama (1995) asserted that the social capital is the existence of a certain set of informal values or norms shared among the members of a group that permit cooperation among them. Sobel (2002) corroborated their positions by describing social capital as conditions in which individuals can benefit from group membership. This implies that the social capital refers to the social life-networks, norms and trust that allow households to act together more successfully to follow communal objectives (Putnam, R.D., 1993; Coleman, J.S., 1990). There is a broad harmony amongst scholars that social capital can be used as a breakthrough to achieve community based health insurance plan in the community among the rural dwellers of Sokoto state, Nigeria.

Considering the idea of Social Health Insurance in Nigeria, it is first mooted in 1962 by Haevi Committee, which passed the proposal through the Lagos Health Bill presented to parliament. The bill was not passed, until 1984 when the campaign re-enacted. The desire to source for funds on health care services made the National Council on Health under Admiral Patrick Koghoni, (the Minister of Health) set up a committee chaired by Professor Diejomoh, which advised the government on the desirability of Health insurance plan in Nigeria and recommended its adoption as a way to fund the health sector. In Nigeria, the Formal Sector, Social Health Insurance Programmed was first introduced in 2005.

In Nigeria priorities include reducing the morbidity and mortality rates due to communicable diseases to the barest minimum; reversing the increasing prevalence of non-communicable diseases; meeting the global targets on the elimination and eradication of diseases, and significantly increasing the life anticipation and quality of life of Nigerians (Federal Ministry of Health 2004).

Nigeria's over-riding objectives since independence in 1960 has been to achieve stability, material prosperity, peace and social progress. However, this has been hampered as a result of internal problems. These include inadequate human capital development, weak infrastructure, and uninspiring growth Health sector, manufacturing sector, unemployment, the poor regulatory environment and mismanagement and misuse of resources.

The persistence of these problems is not unconnected with institutional failure. The institute is only the lack of or weak capacity for efficient service delivery by organizations. It is an established fact that the level of development of any society is influenced by so many factors including functional institutions (Ubi, Effiom and Mba, 20011). Institutions are understood as "formal and informal rules, enforcement characteristics of rules, and standards of behavior that structure repeated social interaction", between individuals, within or between organizations, through incentives, disincentives, constraints and enhancement (North's, 1989) Thus, the key part of any local government, state or national level is service delivery to its citizenry through its institutions. Hence, due to successive failure of the previous governments in Nigeria to provide its community with affordable health care services across all the three tiers of government there is a need to bring in health care reform in the form of social security in which emphasis should be laid on both the formal and informal sector in Sokoto State, Nigeria.

In view of the above, this article is urging the various three tiers of government in Nigeria to embrace the mechanism of community base health insurance plan as the only way forward of providing quality and access able health care for the majority of Nigerians that resides in our rural communities as a way forward. Also by providing subsidies to the vulnerable in our societies will also provide these communities based health insurance schemes with the needed funds to provide and procure drugs and other equipment to serve the people. It is not good to say that since the official flag up of the insurance scheme in the formal sector in 2005 up till now our numerous population in the rural areas are now living without some form of insurance there exposing them to paying from out-of-pocket any time they are seeking medical care. 


\section{References}

[1]. A.S. Preker. (2002). Effectiveness of Community Health Financing in Meeting the Cost of Illness. Bulletin of the WHO, 80(2), $143-150$.

[2]. Ajilowo J B. (2007). Accessibilty of Rural Dwellers to Health Care Facilities in Nigeria: The Owo Region Experience. Pakistan Journal of Social Science, 4(1), 44-55.

[3]. Andersson, N., \& Marks, S. (1987). Work and health in Namibia: preliminary notes. Journal of Southern African Studies, 13(2), 274-292.

[4]. Atim, C. (1998). Contribution of Mutual Health Organization to Funding, Delivery and Access to Health Care: Systhesis of Research in nine West and Central African Countries.

[5]. Atim CB, Diop FP, E. J. et al. (1998). The Contribution of Mutual Health Organizations to Financing, Delivery, and Access in Health Care in West Africa: Summaries and Case Studies in Six Countries. doi:No 19

[6]. Authority, A. N. H. I. (2011). National Health Insurance Scheme Annual Report Accra.

[7]. Baker J., van de Gaag, J. (1993). Equity in Health Care and Health Care Financing. Evidence from Five Developing Countries. In Equity in the Finance and Delivery of Health Care.

[8]. Baron, R.M., and Kenny, D. A. (1986). The Mediator-Variable Disfaunction in Social Psychological Reasearch: Conceptual Strategic and Statistical Considerations. Personalityand Social Psychology, 51((6)), 1173-1182.

[9]. Bennett S, Creese A, M. R. (1998). Health Insurance Scheme for People Outside Formal Sector Employment. Geneva.

[10]. Bennett S, Kelley AG, Silvers B, G. R. and S. L. (2004). "21 Questions on CBHF: An Overview of Community-Based Health Financing

[11]. Binagwaho, A, HARTWIG, R, Ingeri, D., and Makaka, A. (2012). Mutual Health Insurance and its Contribution to Improving Child Health in Rwanda.

[12]. Churchill C. (2006). What is Insurance for the Poor? In PROTECTING The Poor.

[13]. Coleman JS. (1990). Foundations of Social Theory. Cambridge/London

[14]. Creese A, Bennett S, George J. Schieber, E. (1997). Rural Risk-Sharing Strategies In: Inovations in Health Care Financing (No. 365) (pp. 163-82). washinton D.C.

[15]. Creese, A., Benneth, S., Schieber, G. (ed. . (1997). Rural Risk-Sharing Strategies. In Inovations in Health care Financing. washinton D.C.

[16]. Criel, B. (n.d.). District-Based Health Insurance in Sub-Saharan Africa. Part 1: Case-Studies. Studies.

[17]. De Allegri, M., Sauerborn, R., Kouyaté, B., \& Flessa, S. (2009). Community health insurance in sub-Saharan Africa: what operational difficulties hamper its successful development? Tropical Medicine \& International Health, 14(5), 586-596.

[18]. Denscomble, M. (2003). The Good Research Giudefor Small Scale Social Research.

[19]. Dercon, S. (2004). Risk, Insurane, and Poverty: A Review. Insurance Against Poverty, P 9.

[20]. Dercon, S., Gunning, J. W., Zeitlin, A, and Lombardini, S. (2012). The Impact of a Health Insurance Programme: Evidence from a Randomized Controlled Trial in Kenya.

[21]. Dong, H. . kouyate, B. . C. J. and S. R. (n.d.). "Differential Willingness of Household Head to Pay Community-Based health Insurance Premia for themselves and other Household Members." hEALTH Policy Planning, 19, 120-126.

[22]. Dong, H., kouyate, B., Carin, J., and Sauerborn, R. (2005). "Inequalities in Willingness -to-Pay for Community-Baesd Health Insurance." Health Policy, 72, 149-156.

[23]. Dong, H., kouyate, B., Carin, J., Mugisha, F. and Sauerborn, R. (2003). No Title 'Willingness -to-Pay for Community-Based Insurance in Burkina Faso. HEALTH pOLICY, 64, 153-162.

[24]. Dong, H., kouyate, B., Gbangou, A., Mugisha, F. and Sauerborn, R. (n.d.). "The Feasbility of Community- Based Health Insurance in Burkina Faso." Health Policy, 69, 45-53.

[25]. Fitapatrick, A, Magnoni, B,. ANDThornton, R. L. (2011). Microinsurance Utilization in Nicaragua.

[26]. Fukuyama, F. (1995). Trust: The Social Virtues and the Creation of Prosperity.

[27]. G, M. (1990). Financing Health Services in Africa: An Assessment of Alternative Approaches (No. 457).

[28]. G. Carrin, J. (2004). Reading Universal Coverage via Social Health Insurance: Key Design Features in the Transition Period. (Vol. 2).

[29]. G. Sudhakar, G. Nandab Kumar, M. Sreenivas, ..P. Srinivas. (2013). Communication- The Major Stress or for MBA StudentsTechniques to Handle it Successfully. Marketing, Financial Services \& Management Research, 2(11).

[30]. Galarraga, O., Sosa-Rubi, S. G., Salinas-Rodriguez, A., and SESMA-vAZQUES, S. (2010). Health Insurance for the Poor: Impact on Catastrophic and Out -of-Pocket Health Expenditures in Mexico. European Journal of Health Economics,, 11((5)), $437-447$.

[31]. Giedion, u., Alfonso, E.A., and Diaz, Y. (2013). The Impact of Universal Coverage Schemes in the Developing World:a Review of the Existing Evidence (pp. 2-5). washinton D.C.

[32]. Gilson, L., andA. M. (1995). Health sector Reforms in Sub-Saharan Africa: Lesson of the Last 10 Years. Health Policy, 32(1-3), 215-43.

[33]. Gumber, A. (2001). Hedging the Health of the Poor: The casefor Community Financing in India Nutrition and Population Discussion Paper (No. 28875).

[34]. Gustafsson-Wright, E., Tanovic, Z., van der Gaag, J. (2013). The Impact of Private Subsidized Health Insurance and Clinic Upgrades on Health Care Utilization and Financial Protection on Rural Nigeria.

[35]. Gustafsson-Wrigth, E. (2013). A short- term Impact Evaluation of the Health Insurance Fund Programin Central Kwara State, Nigeria.

[36]. Jakab M, Preker A, K. C. et al. (2001). Social Inclusion and Financial Protection through Community Financing: Initial Results from Five Household Surveys. Macroeconomics and Health.

[37]. Joint Learning Network Ghana. (2011). National Health Insurance Scheme (NHIS). Retrieved from http://joinlearningnetwork.org/content/national.health.insurance.scheme.nhis

[38]. Jutting, J. (2001). "The Impact of Health Insurance on the Access to Health Care and Financial Protection in Rural areas of Developing Countries: The Example of Senegal.” Retrieved from http://www.zef.de

[39]. Jutting, J. P. (2004). Do Community-Based Health Insurance Schemes Improve Poor Peoples Accesss to Health Care? Evidence from Rural Senegal. World Development, 32((2):273288).

[40]. Kamien, M. I., \& Schwartz, N. L. (1973). Payment Plans and the Efficient Delivery of Health Care Services. Journal of Risk and Insurance, 427-436.

[41]. Kamuzora, P., and Gilson, L. (2007). Factors Influencing Implementation of the Community Health Fund in Tanzani. hEALTH Policy Planning, 22((2)), 95-102. 
[42]. King, G., Gakidou, E., Imai, K., Kakin. J., Moore, R. T., Nail, C., ... and Llamas, H. H. . (2009). Public Policy for Poor? A Randomised Assessment of the Mexican Universal Health Insurance Programme. The Lancet.

[43]. Lambo, E., \& Sambo, L. G. (2003). Health sector reform in sub-Saharan Africa: a synthesis of country experiences. East African Medical Journal, 80(6), S1-S20.

[44]. Lampton, D. M. (1974). Health Policy During the Great Leap Forward. The China Quarterly, 60(1), $668-698$.

[45]. Lei, X. and Lin, W. (2009). The New Cooperative Medical Scheme in Rural China: Does more Coverage Mean more Service and Better Health? Health Economics, 18((S2)S25S46).

[46]. Levine, D. and Polimeni, R. (2012). Insuring Health or Insuring Wealth? An Experimental Evaluation of Health Insurance in Rural Cambodia.

[47]. Makinen M, Sealy S, Bitran R, Adjei S, M. R. (2011). Private Health Sector Assessment in Ghana. washinton D.C.

[48]. McGuire W. (1989). Theoritical Foundations of Campaigns, 43-65.

[49]. McNamara, C. (2009). No Title.

[50]. McPake B. (1993). User Charges for Health Services in Developing Countries. Social Science and Medicine, 36, $1397-1405$.

[51]. Miles, M. and Hurberman, M. (1994). No Title.

[52]. Mugisha F, Kouyate B, Dong H, S. R. (2009). Costing Health Care Interventions at Primary Health Facilitiesin Nouna, Burkin Fa so. African Journal of Health Sciences, 9, 63-73.

[53]. Musau S. (1999). Community Based Health Insurance: Experiences and Lessons Learned from East and Southern Africa. doi:NO .34

[54]. Musau, S. (1999). Community-Based Health Insurance: Experience and Lessons Learned from East Africa. N.

[55]. NDHS. (2008). National Population Commission, Nigeria Demographic and Health Survey.

[56]. NPC. (2006). National Population Commission, Population Census of the Federal Republic of Nigeri

[57]. Ombeline De Book., D. U. O. (2013). Literature Review on the Impact of Micrinsurance (Vol. No. 35). Geneva.

[58]. Onwujekwe O, V. E. (2006). Feasibility of Voluntary Health Insurance in Nigeria. washinton D.C.

[59]. Opaluwa, H. I., Otitolaiye, J. O., \& Onuche, U. (2010). Accessibility to Improved Health Care as a Means to Economic Empowerment in Rural Kogi State, North Central, Nigeria. Research Journal of Agriculture and Biological Sciences, 6(6), 10361041 .

[60]. Orasz Eva and Morgan, D. (2004). SHA- Based National Health Accounts in thirteen OECD Countries: A Comparative Analysis

[61]. P., S. (2005). Trust in Micro-Health Insurance: An Exploratory Study in Rwanda. Social Science and Medicine, 61, $1430-1438$.

[62]. Palmer N., Mueller DH., Gilson L., M. A. and H. A. (2004). Health Financing to Promote Access in Low Income Settings- How Much do we Know? Lancet, 364, 1365-1370.

[63]. Putnam R. D. (1993). Making Democracy Work. Civic Traditions in Modern Italy.

[64]. Release, P. (2008). National Health Insurance Scheme and MDG Office, N igeria.

[65]. RW., P. (1995). Knowledge Utilization and the Process of Policy Formulation: Towards a Framework for Africa. washinton D.C.

[66]. S, B. (2011). The Impact of User Fees on Access to Health Services in Low and Middle-Income Countries. (No. 4)

[67]. Sobel J. (2002). Can we Trust Social Capital? Journal of Economic Literature, 40(1), 139-154.

[68]. United Republic of Tanzania. (2003). Assessment of Community Health Fund in Tanzania: Factors Affecting Enrolment and Coverage.

[69]. Usoroh, E. E. (2012). Achieving Universal Health Coverage in Nigeria: The National Health Insurance scheme as a Tool., 16-17.

[70]. WHO. (2000). World Health Report 2000- Health Systems: Improving Performance.

[71]. WHO. (2002). WHO Country Cooperation Strategy: Federal Repblic of Nigeria 2002-2007.

[72]. WHO. (2005). The World Health Report: Make Every Mother and Child Count. Geneva.

[73]. WHO. (2010). Health System Financing: The Path to Universal Coverage

[74]. Wietler, K. (2010). Mutual health organizations in sub-saharan Africa-Opportunities and challenges. Discussion Papers on Social Protection.

[75]. World Bank. (2005). Nigeria: Health, Nutrition, and Population Country Status Report. 